\title{
KEMAMPUAN AWAL KALKULUS MAHASISWA PENDIDIKAN MATEMATIKA
}

\author{
Khairudin \\ Program Studi Pendidikan Matematika FKIP Universitas Bung Hatta, \\ Kampus Proklamator 2, Jalan Bagindo Aziz Chan Aia Pacah By Pass, Padang \\ e-mail: khairuddin@bunghatta.ac.id
}

\begin{abstract}
Abstrak
Penelitian bertujuan untuk mendeskripsikan tingkat kemampuan awal Kalkulus mahasiswa Pendidikan Matematika FKIP Universitas Bung Hatta tahun pertama. Metode penelitian menggunakan metode deskriptif. Subjek penelitian adalah mahasiswa yang mengambil mata kuliah Kalkulus Diferensial pada semester kedua. Instrumen penelitian menggunakan tes diagnostic yang dikembangkan oleh Stewart dengan materi aljabar, Geometri, Trigonometri, dan Fungsi serta wawancara terhadap peserta. Tenik analisis data menggunakan analisis dekriptif. Berdasarkan hasil penelitian, terlihat bahwa kemampuan awal mahasiswa berada pada tingkat sangat rendah, yaitu $8,6 \%$. Hasil wawancara terhadap 6 orang mahasiswa yang mempunyai kemampuan skor tinggi, sedang, dan rendah menyatakan bahwa mahasiswa memerlukan tambahan pengetahuan tentang konsep bilangan serta sifat-sifatnya, operasi aljabar, visualisasi dengan teknologi serta konsep fungsi. Berdasarkan hasil tersebut, diperlukan strategi pembelajaran pada mata kuliah Kalkulus yang berbasis teknologi untuk memberi pemahaman konsep Kalkulus.
\end{abstract}

Kata Kunci: kemampuan awal, tingkat kemampuan awal, strategi pembelajaran.

\begin{abstract}
The research aimed to describe the initial ability level of Mathematics Education in the first year of the Mathematics Education Faculty of Bung Hatta University. The research method used descriptive. The research subjects were students who took Differential Calculus courses in the second semester. The research instrument used diagnostic tests developed by Stewart with algebraic material, Geometry, Trigonometry, and Functions as well as interviews with participants. Data analysis techniques used descriptive analysis. Based on the results of the research, it appeared that the initial ability of students is at a very low level, which is $8.6 \%$. The results of interviews with 6 students who have the ability to score high, medium, and low stated that students need additional knowledge about the concept of numbers and their properties, algebraic operations, visualization with technology and the concept of functions. Based on these results, a learning strategy for technology-based Calculus is needed to provide an understanding of the Calculus concept.
\end{abstract}

Keywords: prior knowledge, grade of prior knowledge, learning strategy.

\section{PENDAHULUAN}

Materi Matematika yang diberikan pada mahasiswa tahun pertama pada umumnya adalah materi Kalkulus, karena banyak terdapat konsep aplikasi diberbagai bidang, bukan hanya di Pendidikan Matematika dimana sebagai calon guru yang akan mengajarkan konsep Kalkulus di sekolah menengah atas dan dibutuhkan untuk memahami mata kuliah lanjut yang bersifat analisis. Namun ada 
juga pada bidang Teknik, Ekonomi, Biologi, Kedokteran, dan lainnya dibutuhkan tiap pokok bahasan dalam Kalkulus, misalnya fungsi, Limit, Turunan, Integral (Larson, 2009). Khususnya untuk bidang Industri, penggunaan teori optimalisasi yang merupakan bagian dari Kalkulus, dalam pengambilan keputusan yang berhubungan dengan efisiensi, efektivitas, maksimisasi keuntungan, dan minimisasi biaya/kerugian (Kartono, 2003).

Teori Integral digunakan untuk menyelesaikan: (1) Pengukuran keluaran darah dari jantung; (2) Mengubah energi menjadi gerak otot; (3) Pengukuran volume darah yang mengalir dalam pembuluh darah; dan (4) Pengukuran banyaknya polutan yang memasuki ekosistem (Burhanuddin, 2013). Namun demikian, untuk dapat menerapkan konsep Kalkulus tersebut, tentu harus menguasai konsep-konsep dasarnya. Kalkulus memuat materi yang bersifat abstrak dan sangat kental dengan simbol-simbol dan logika.

Pemahaman terhadap suatu konsep harus ditopang oleh pemahaman konsep lain terlebih dahulu. Mahasiswa tahun pertama, karena berlatar belakang bukan saja dari sekolah yang heterogen, juga terdapat dari sekolah yang sangat minim pengetahuan Matematika. Hal tersebut berdasarkan observasi peneliti sebagai dosen Kalkulus di Program Studi Pendidikan Matematika, Pendidikan Teknik Informatika dan Komputer dan Teknik sipil sejak tahun 1994 hingga sekarang di Universitas Bung Hatta. Hasil Belajar Kalkulus untuk tiga tahun akademik cenderung mengalami penurunan dengan kategori baik (B) dan sangat baik (A) (Khairudin, dkk., 2020) dan capaian kemampuan pemahaman matematis mahasiswa pada mata kuliah kalkulus masih kurang optimal (Hartati, 2019).

Fakta yang terjadi yang berkaitan dengan pembelajaran Kalkulus tahun pertama terlihat bahwa dosen Kalkulus merasa kesulitan dalam mengajarkan materi Kalkulus karena mahasiswa tidak menguasai materi kemampuan awal Kalkulus (Prior Knowledge of Calculus). Kemampuan awal adalah kemampuan yang berasal dari pengalaman sebelumnya dan diperoleh ketika di Sekolah Menengah Atas (SMA) atau sederajat, seperti Aljabar, Geometri, Trigonometri, dan Fungsi sederhana. Hal tersebut karena mahasiswa berasal dari berbagai sekolah yang kurang kemampuan Matematikanya (Sabirin, dkk., 2017; Amalia, 
2016; Ario, 2019; Samo, 2017). Namun penelitian sebelumnya kurang merinci materi yang sesuai dengan kebutuhan Kalkulus di perguruan tinggi.

Kurangnya kemampuan mahasiswa tahun pertama karena kurangnya pemahaman dan kemampuan guru dalam menyampaikan pelajaran dan guru mengalami kesulitan dalam mengajarkan konsep karena keterbatasan guru menguasai subjek (Desfitri, 2016) dan kurangnya pengetahuan guru dalam menganalisis kesalahan dalam kalkulus diferensial (Moru, et al., 2014). Berdasarkan hal tersebut berakibat terhadap kemampuan siswa dalam menguasai konsep Matematika SMA yang merupakan pengetahuan awal Matematika untuk melanjutkan ke perguruan tinggi. Padahal terdapat pengaruh kemampuan awal Matematika terhadap kemampuan berpikir logis dan kemandirian belajar (Aminah, dkk., 2018). Hal tersebut sesuai dengan hasil penelitian yang memperlihatkan kemandirian belajar siswa masih rendah ( Khairudin, dkk., 2020).

Berdasarkan fakta yang dikemukakan tersebut, maka tujuan penelitian adalah untuk mendeskripsikan tingkat kemampuan awal Kalkulus mahasiswa tahun pertama Program Studi Pendidikan Matematika Fakultas Keguruan dan Ilmu Pendidikan (FKIP) Universitas Bung Hatta dan bagaimana pendapat mahasiswa dalam memahami konsep Kalkulus.

\section{METODE}

Metode penelitian menggunakan metode deskriptif yang bertujuan untuk menggambarkan tingkat kemampuan awal Kalkulus mahasiswa Pendidikan Matematika FKIP Universitas Bung Hatta pada saat mengikuti perkuliahan Kalkulus Diferensial. Populasi penelitian adalah mahasiswa tahun pertama Pendidikan Matematika FKIP Universitas Bung Hatta yang mengambil mata kuliah Kalkulus Diferensial pada semester 2 tahun akademik 2019/2020. Karena jumlah mahasiswa tahun pertama adalah 19 orang, maka langsung menjadi sampel (total sampling). Instrumen yang digunakan adalah test diagnostic yang terdapat pada buku Stewart (2010).

Peneliti hanya mengambil bagian yang dominan dalam mendukung pembelajaran Kalkulus Diferensial dan sesuai dengan Rencana Pembelajaran 
Semester (RPS) Program Studi Pendidikan Matematika Universitas Bung Hatta. Tes diberikan ketika awal pertemuan, setelah diberikan gambaran umum perkuliahan Kalkulus Diferensial serta materi yang diperlukan berupa handout dan buku-buku refrensi dalam bentuk buku digital. Uji coba terhadap tes kemampuan awal tidak perlu dilakukan karena instrumen dari buku Kalkulus standar yang sudah diakui dan banyak digunakan oleh dosen serta sudah melalui diskusi dengan 4 orang guru di SMA.

Sebaran soal yang dipilih dengan rincian 6 item soal Aljabar, 6 item soal Geometri, 5 item soal Trigonometri, dan 6 item soal Fungsi sehingga berjumlah 22 soal. Setiap bagian soal diberikan berdasarkan kelompok soal dengan waktu terbatas melalui power point dengan waktu 3 menit per soal. Setiap soal diberi skor 1 jika benar dan 0 jika salah. Berdasarkan pemberian skor yang diberikan, maka teknik analisis data menggunakan tingkat penguasaan seperti pada Tabel 1.

Tabel 1 Tabel Tingkat Kemampuan Awal Kalkulus

\begin{tabular}{ccc}
\hline Kelompok & Tingkat Penguasaan $\mathbf{( P \% )}$ & Skor \\
\hline Tinggi & $75 \leq \mathrm{P} \leq 100$ & $16-22$ \\
Sedang & $50 \leq \mathrm{P}<75$ & $11-15$ \\
Rendah & $25 \leq \mathrm{P}<50$ & $6-10$ \\
Sangat Rendah & $\mathrm{P}<25$ & $0-5$ \\
\hline
\end{tabular}

Skor secara kelompok menggunakan rumus (Khairudin, dkk., 2020) berikut.

$$
P=\frac{n}{N} \cdot 100 \%
$$

Keterangan: $\mathrm{P}$ adalah Persentase nilai yang diperoleh; $\mathrm{n}$ adalah jumlah skor yang diperoleh; dan $\mathrm{N}$ adalah jumlah seluruh skor nilai ideal.

Instrumen wawancara tidak terstruktur dengan berpedoman terhadap beberapa pertanyaan yang berkaitan dengan tes yang diberikan, yaitu: (1) Apa yang menyebabkan peserta tidak dapat menjawab soal tersebut? (2) Mengapa peserta menggunakan konsep yang salah dalam menyelesaikan soal tersebut? (3) Apa yang menyebabkan peserta mampu menjawab soal tetapi hasilnya salah? dan (4) Bagaimana pendapat atau saran peserta untuk dapat memahami konsep Kalkulus? 


\section{HASIL DAN PEMBAHASAN}

Data hasil kemampuan awal matematis mahasiswa Pendidikan Matematika diperoleh dari tes tertulis yang berisi 22 soal esai. Deskripsi hasil kemampuan untuk menjawab soal perindikator soal terlihat pada Gambar 1.

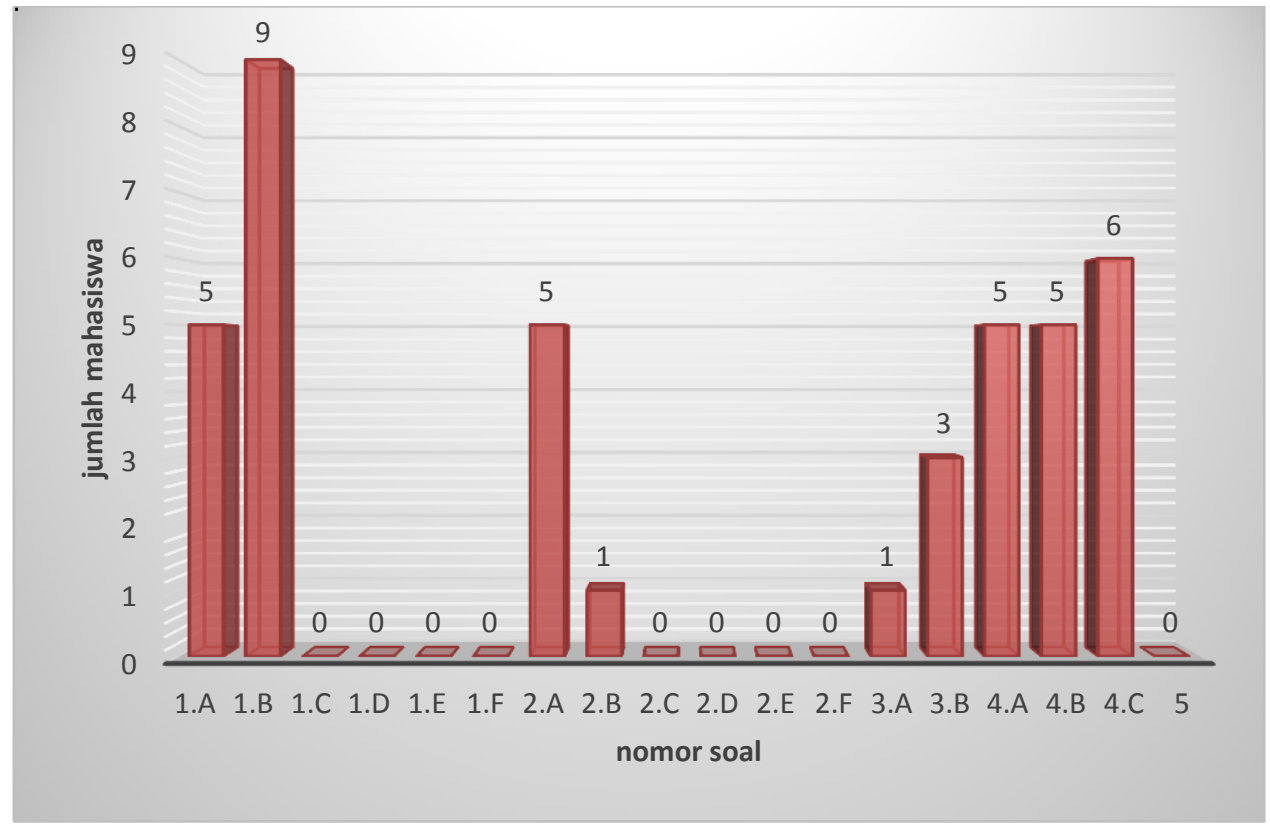

\section{Gambar 1 Jumlah Soal Terjawab Tiap Peserta}

Berdasarkan Gambar 1, terlihat bahwa soal-soal yang dapat terjawab untuk soal Aljabar adalah soal 1a sebanyak 5 orang (12,5\%), soal 1b sebanyak 9 orang $(22,5 \%)$, serta tidak ada yang dapat menjawab soal 1c, 1d, 1e, dan 1f. Soal Geometri yang terjawab adalah soal $2 \mathrm{a}$ sebanyak 5 orang $(12,5 \%)$, soal $1 \mathrm{~b}$ sebanyak 1 orang $(2,5 \%)$, serta tidak ada yang dapat menjawab soal $2 \mathrm{c}, 2 \mathrm{~d}, 2 \mathrm{e}$, dan 2f. Soal Trigonometri yang dapat terjawab adalah soal 3a sebanyak 1 orang $(2,5 \%)$, soal 3 b sebanyak 3 orang $(7,5 \%)$, soal 4a sebanyak 5 orang $(12,5 \%)$, soal 4b sebanyak 5 orang (12,5\%), dan soal 4c sebanyak 6 orang (15\%). Tidak ada seorangpun yang dapat menjawab soal tentang fungsi yang berjumlah 6 soal.

Berdasarkan hasil lembar jawaban siswa diperoleh deskripsi tingkat penguasaan kemampuan awal mahasiswa seperti yang terlihat pada Tabel 2 . 
Tabel 2 Hasil Skor Kemampuan Awal Kalkulus

\begin{tabular}{ccccc}
\hline No & $\begin{array}{c}\text { Jumlah } \\
\text { Skor }\end{array}$ & $\begin{array}{c}\text { Banyaknya } \\
\text { Mahasiswa }\end{array}$ & $\begin{array}{c}\text { Total } \\
\text { Skor }\end{array}$ & Kategori \\
\hline 1 & 9 & 1 & 9 & Rendah \\
2 & 5 & 1 & 5 & Sangat Rendah \\
3 & 4 & 2 & 8 & Sangat Rendah \\
4 & 3 & 2 & 6 & Sangat Rendah \\
5 & 2 & 4 & 8 & Sangat Rendah \\
6 & 1 & 4 & 4 & Sangat Rendah \\
7 & 0 & 5 & 0 & Sangat Rendah \\
\hline & Jumlah & $\mathbf{1 9}$ & $\mathbf{4 0}$ & \\
\hline
\end{tabular}

Tabel 2 memperlihatkan bahwa secara individu hanya 1 (satu) orang yang memperoleh skor 9. Hal tersebut berarti kemampuan awal Kalkulus mahasiswa Pendidikan Matematikan FKIP Universitas Bung Hatta, hanya 1 (satu) orang yang berada pada tingkat rendah dan selebihnya berada pada tingkat sangat rendah. Secara umum, kemampuan awal Kalkulus mahasiswa berada pada kategori sangat rendah, yaitu $\mathrm{P}=8,6 \%$ berdasarkan rumus (1).

Selanjutnya secara rinci dibahas kemampuan mahasiswa berdasarkan jenis soal yang diberikan serta hasil wawancara. Pada pertanyaan topik Aljabar yaitu nomor 1, dengan 6 sub pertanyaan untuk menyelesaikan masalah aljabar (gambar
2), yaitu: (a) $\left(\frac{2}{3}\right)^{-2}$
(b) $\sqrt{200}-\sqrt{32}$
(c) $2 x^{2}+5 x-12=0$
(d) $\frac{x^{2}}{x^{2}-4}-\frac{x+1}{x+2}=0$
(e) $x(x-1)(x+2)>0$ dan
(f) $x^{2}<2 x+8$

Terdapat banyak hal yang tidak dipahami oleh mahasiswa, antara lain: (1) Mahasiswa tidak memahami operasi pangkat bilangan dan sifat-sifatnya, demikian juga dengan akar bilangan bulat dan strategi pencarian akar bilangan bulat (a dan b); (2) Mahasiswa tidak memahami konsep pemaktoran serta pengurangan pecahan dalam bentuk variabel (c dan d); dan (3) Mahasiswa tidak memahami konsep himpunan penyelesaian pertaksamaan dan langkah-langkah menyelesaikan pertaksamaan (e dan f). 

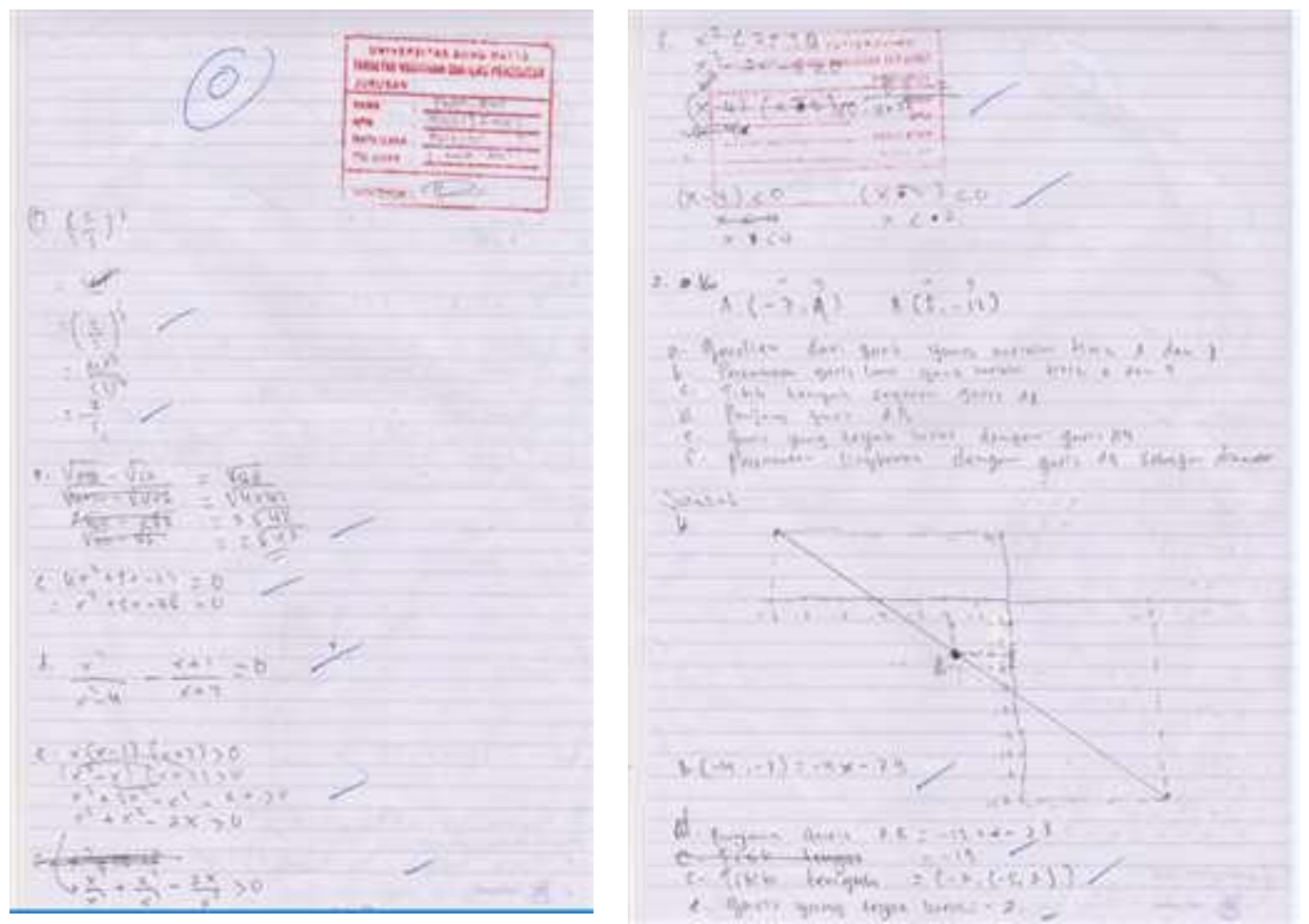

\section{Gambar 2 Lembar Jawaban Mahasiswa Topik Aljabar dan Geometri}

Selanjutnya pertanyaan nomor 2 adalah menyelesaikan masalah geometri, yaitu diketahui dua titik $\mathrm{A}(-7,4)$ dan $\mathrm{B}(5,-12)$ adalah sebidang, mahasiswa menentukan: (a) Gradien (slope) dari garis yang melalui titik A dan B; (b) Persamaan garis lurus yang melalui titik A dan B; (c) Titik tengah segmen garis AB; (d) Panjang garis AB; (e) Garis yang tegak lurus dengan garis AB; dan (f) Persamaan lingkaran dengan garis $\mathrm{AB}$ sebagai diameter. Hasil jawaban mahasiswa terlihat pada Gambar 2. Pada gambar 2, terlihat bahwa mahasiswa tidak memahami konsep kemiringan (gradien). Mahasiswa memahami sistem koordinat kartesius, namun tidak dapat membentuk persamaan garis lurus dan persamaan lingkaran serta sifat-sifatnya.

Berdasarkan soal Trigonometri, yaitu soal nomor 3 menyelesaikan masalah mengkonversikan sudut dari derajat ke dalam radian: a. $300^{\circ}$, b. $-18^{0}$, serta soal nomor 4 menentukan nilai: a. $\cos \left(300^{\circ}\right)$, b. $\sin (7 \pi / 6)$, c. $\tan (\pi / 3)$, diperoleh hasil seperti Gambar 3. Pada Gambar 3, terlihat bahwa mahasiswa tidak memahami konsep sudut dalam sistem derajat dan sistem Radian, sehingga tidak dapat mengkonversi nilai derajat kedalam Radian atau sebaliknya. Demikian juga 
mahasiswa tidak dapat memahami konsep fungsi Trigonometri, sehingga tidak dapat menghitung nilai trigonometri dalam bentuk derajat ataupun dalam bentuk Radian. Sementara untuk tes pemahaman fungsi disajikan suatu grafik fungsi, mahasiswa diminta untuk menentukan nilai fungsi dibeberapa titik atau sebaliknya serta menentukan daerah asal (domain) serta daerah hasil (Range), maka tidak ada yang dapat menjawabnya, sehingga dapat dinyatakan bahwa mahasiswa belum memahami konsep fungsi.

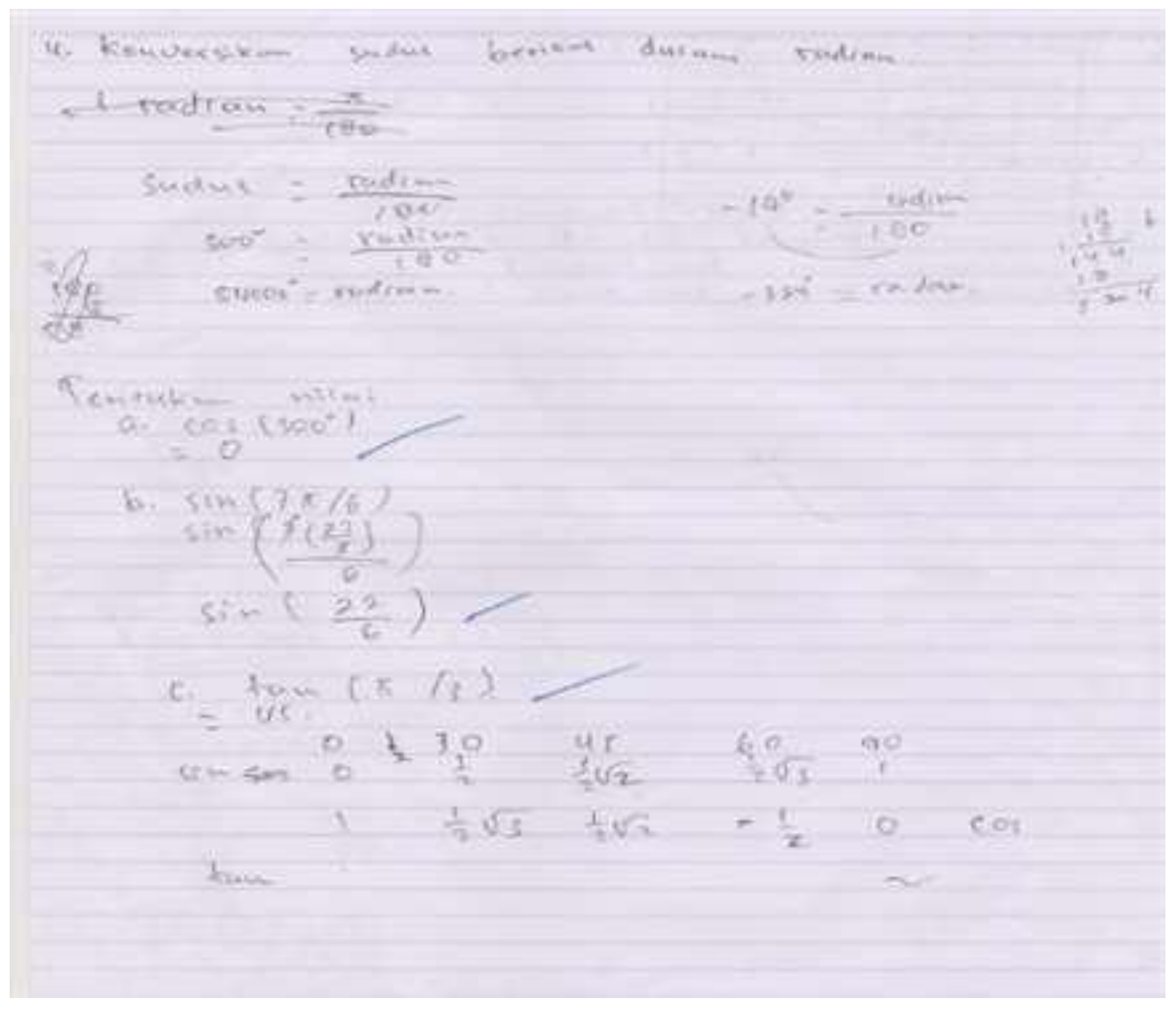

\section{Gambar 3 Lembar Jawaban Topik Trigonometri}

Berdasarkan hasil tes diagnostik, dilakukan wawancara terhadap mahasiswa dan diminta saran untuk pemahaman konsep kemampuan awal Kalkulus, maka diberikan 4 pertanyaan, sebagai pedoman dalam wawancara terhadap 6 orang kemampuan tinggi, sedang, dan rendah, yaitu: (1) Apa yang menyebabkan Anda tidak dapat menjawab soal tersebut? Jawaban mahasiswa khususnya tentang fungsi, bahwa 6 orang menyatakan tidak memahami konsep tersebut, khususnya 
yang terkait dengan menentukan domain dan Range; (2) Mengapa Anda menggunakan konsep yang salah dalam menyelesaikan soal tersebut? Terdapat 4 orang menjawab bahwa mahasiswa belum mengenal sifat-sifat aljabar bilangan, operasi aljabar dan sangat lemah dalam visualisasi grafik, selebihnya menjawab tidak tahu cara menyelesaikannya; (3) Apa yang menyebabkan Anda mampu menjawab soal tetapi hasilnya salah? 3 orang menjawab kurang teliti dan 3 orang menjawab coba-coba; dan (4) Bagaimana saran Anda untuk dapat memahami konsep Kalkulus? Semua mahasiswa menjawab pentingnya mengulang kembali konsep yang mendasar untuk mendukung perkuliahan, khususnya konsep bilangan dan operasinya, visualisasi grafik jika perlu menggunakan teknologi serta pemahaman konsep fungsi. Ada juga yang menggunakan konsep yang keliru dalam menjawab soal. Kemudian terdapat juga langkah yang sudah benar tetapi hasil akhir salah.

Berdasarkan hasil wawancara dengan mahasiswa, perlu para dosen Kalkulus untuk memahami kesulitan mahasiswa dalam pemahaman konsep awal seperti (Ladachart, (2019). Harus ada kerangka kerja (framework) yang memuat 4 (empat) tujuan akhir dalam memahami kalkulus tahun pertama, yaitu: (1) Penguasaan konsep dasar dan keterampilan kalkulus tahun pertama; (2) Membangun koneksi/hubungan antara konsep dan keterampilan; (3) Kemampuan untuk menggunakan ide-ide kalkulus tahun pertama; dan (4) pemahaman mendalam tentang konteks dan tujuan kalkulus (Sofronas, et al., 2011). Apabila hal tersebut dilaksanakan, maka dapat diperoleh hasil belajar yang baik, karena terdapat pengaruh kemampuan awal terhadap hasil belajar (Lestari, 2017; Firmansyah, 2017; Hevriansyah dan Megawanti, 2017).

\section{SIMPULAN}

Berdasarkan hasil analisis data penelitian, diperoleh bahwa secara umum kemampuan awal Kalkulus mahasiswa Pendidikan FKIP Universitas Bung Hatta berada pada tingkat sangat rendah. Topik Aljabar dasar yang kurang dipahami mahasiswa adalah dalam perpangkatan bilangan, akar bilangan, dan penyeleseaian persamaan atau pertaksamaan. Mahasiswa kurang mampu menyelesaikan dan 
memnggambarkan garis lurus serta lingkaran, mahasiswa tidak mampu mengkonversi sudut atau menentukan nilai fungsi trigonometri. Hal yang sangat mendasar adalah mahasiswa tidak menguasai konsep fungsi. Padahal konsep fungsi adalah hal yang sangat mendasar dalam memahami Kalkulus, karena konsep Limit, konsep Turunan, dan Konsep Integral berkaitan dengan fungsi. Hal ini menunjukkan bahwa selain kualitas input mahasiswa kurang baik, juga diperlukan langkah-langkah praktis dengan usaha keras untuk merancang suatu pembelajaran yang bervariasi dibantu dengan penggunaan aplikasi komputer sehingga dapat meningkatkan hasil pembelajaran yang baik.

\section{DAFTAR PUSTAKA}

Amalia, R. 2016. Kemampuan Berpikir Matematis Mahasiswa dalam Menyelesaikan Masalah Geometri. Jurnal Pendidikan Matematika, 4(2): $118-125$.

Aminah, M., Kusumah, Y. S., Suryadi, D., \& Sumarmo, U. 2018. The Effect of Metacognitive Teaching and Mathematical Prior Knowledge on Mathematical Logical Thinking Ability and Self-Regulated Learning. International Journal of Instruction, 11(3): 45-62.

Ario, M. 2019. Profil Kemampuan Awal Matematis Mahasiswa Pendidikan Matematika. Jurnal Absis: Jurnal Pendidikan Matematika dan Matematika, 1(2): 72-77.

Burhanuddin. 2013. Penerapan Kalkulus Integral pada Bidang Biologi. Jurnal Biology Education, 2(1): 8-13.

Desfitri, R. 2016. In-Service Teachers' Understanding on the Concept of Limits and Derivatives and the Way They Deliver the Concepts to Their High School Students. Journal of Physics: Conference Series, 693: 1-9.

Firmansyah, M. A. 2017. Peran Kemapuan Awal Matematika dan Belief Matematika terhadap Hasil Belajar. Prima: Jurnal Pendidikan Matematika, 1(1): 55-68.

Hartati, L. 2019. Analisis Kemampuan Pemahaman Matematis Mahasiswa pada Mata Kuliah Kalkulus Berdasarkan Teori APOS. Prosiding Seminar Nasional Pendidikan KALUNI, 2(2019): 174-183.

Hevriansyah, P. \& Megawanti, P. 2017. Pengaruh Kemampuan Awal terhadap Hasil Belajar Matematika. JKPM (Jurnal Kajian Pendidikan Matematika), 2(1): 37-47.

Kartono. 2003. Aplikasi Matematika dalam Perencanaan dan Pengendalian di Bidang Industri. Jurnal Matematika dan Komputer, 6(1): 49-58.

Khairudin, Suryani, K., Fauzan, A., \& Armiati. 2020. Self Regulated Learning of Mathematics Education Students of Bung Hatta University. Journal of Physics: Conference Series, 1429 (2020): 1-8. 
Ladachart, L. 2019. Thai Science Educators' Perspectives on Students' Prior Knowledge: A Documentary Research. Science Education International, 30(2): 116-127.

Larson, R. 2009. Calculus: An Applied Approach (Eighth Edi; C. L. Brooks/Cole, ed.). USA: Brooks/Cole, Cengage Learning.

Lestari, W. 2017. Pengaruh Kemampuan Awal Matematika dan Motivasi Belajar terhadap Hasil Belajar Matematika. Jurnal Analis, 3(1): 76-84.

Moru, E. K., Qhobela, M., Wetsi, P., \& Nchejane, J. 2014. Teacher Knowledge of Error Analysis in Differential Calculus. Pythagoras, 35(2): 1-10.

Sabirin, M., Fitria, A., \& Ningsih, S. 2017. Profil Kemampuan Matematika Dasar Mahasiswa Program Studi Pendidikan Matematika Tahun Akademik 2013/2014. Jurnal Pendidikan Matematika, 2(2): 29-42.

Samo, D. D. 2017. Kemampuan Pemecahan Masalah Mahasiswa Tahun Pertama pada Masalah Geometri Konteks Budaya. Jurnal Riset Pendidikan Matematika, 4(2): 141-152.

Sofronas, K. S., DeFranco, T. C., Vinsonhaler, C., Gorgievski, N., Schroeder, L., \& Hamelin, C. 2011. What Does It Mean for A Student to Understand the First-Year Calculus? Perspectives of 24 Experts. Journal of Mathematical Behavior, 30(2): 131-148.

Stewart, J. 2010. Single Variable Calculus: Concepts and Contexts, (4 edition). USA: Brooks/Cole. 